chemistry research based on research reactors. The only other article is a report of the international conference at Padua on direct interactions and nuclear reaction mechanism, hold in September 1962. The Review is to appear irregularly and will apparently replace the series of occasional reviews published individually by the Agency in the past. One is bound to wonder whethor publication in the form of separate reviews was not to be preferred. Publication in a journal of irregular periodicity is bound to cause additional delay; and to have several reviews on widely different subjects in a single cover offers no obvious advantage. For the other proposed contents there is no lack of suitable existing journals.

\section{Erlanger's Scientific Papers and Memoribilia}

Dr. Joseph ERLANGER, professor emeritus of physiology at Washington University School of Medicine, St. Louis, Mo., and Nobel prizewinner in physiology (with Dr. Herbert Gasser) in 1944, has given his scientific papers and memoribilia to the Washington University School of Medicine Library, of which he was one of the founders in 1910. Included in the collection are letters from many famous scientists of the first half of the twentieth century, both American and others, and documents relating to medical education just after the Flexner report. Dr. Erlanger recently celebrated his eighty-ninth birthday. A ceremony to mark this gift will be held on the afternoon of the Washington University School of Medicine's Alumni Day, June 7, 1963. On that occasion Dr. Harvey L. White, at present head of the Department of Physiology, will speak on Dr. Erlanger's work, and Miss Margaret Erlanger will formally present the papers to the School on behalf of her father. A reception and a display of some of the documents will follow. The papers themselves will be micro-filmed for preservation.

\section{The U.S. National Museum}

DURING the year 1961-62, covered by the annual report of the U.S. National Museum (Pp. viii + 195. Washington, D.C.: Government Printing Office, 1962), it was expedient to place two of the largest museum objects in the exhibition galleries of the new building for history and technology. The large 280-ton steam locomotive and tender presented by the Southern Railway System were placed on rails in the Transportation Hall and the original Revolutionary War gunboat Philadelphia was hoisted through a window to the third-floor Military History Hall. Both exhibits, especially the former, must have taxed the ingenuity and resources of the curatorial staff. The report is well illustrated and concludes with a list of publications by staff and donors to the National Collections.

\section{Commonwealth Museums}

The Museums Journal for March 1963 (62, No. 4) is devoted to a series of papers describing some of the more important museums of the British Commonwealth. Concentration on this theme follows naturally on the opening by H.M. The Queen of the new Commonwealth Institute in London, which is described by the director, Sir Kenneth Bradley. Dr. Grace Morley deals with museums in India, and other officers describe museums and art galleries in Canada, Northern and Southern Rhodesia, New Zealand, Ceylon and the Coryndon Museum, Kenya. All the papers describe the latest activities and display methods in the various museums together with abbreviated historical notes concerning their development.

\section{Units and Standards of Measurements employed at} the National Physical Laboratory: Electricity

THE third booklet, Electricity, in the series of four entitled Units and Standards of Measurement employed at the National Physical Laboratory has been brought up to date and the revised edition has recently been published (Pp. ii +16 . London: H.M.S.O., 1962. 1s. 6d. net). It contains a short history of electric units from the London conference in 1908 to the present day, and incorporates the various findings of the international committees, including those of the eleventh General Conference of Weights and Measures, October 1960, on the International System of Units. The absolute standards, reference and working standards, and the legal standards are dealt with in some detail, and a separate section is devoted to the standards of frequency. The contents of the booklet should be particularly valuable to students and teachers, and it is hoped that authors of new text-books will take note of the most recent definitions and units listed in the appendixes.

\section{Minerals in the Infra-Red}

Minerals in the Infra-red is a critical bibliography em. bracing the fields of absorption, reflexion, emission and transmission in minerals and related materials (Pp. xii + 76. Basle and New York: S. Karger, 1962. I dollar). It represents a seven-year investigation undertaken by R. J. P. Lyon, a mineralogist, and paid for by Stanford Research Institute. The infra-red portion of the spectrum was discovered by W. Herschel in 1800 and the first absorption experiments were made in 1881. W. W. Coblentz published the first catalogues of infra-red spectra of minerals during 1905-10. With the development of automatic-recording instrumentation during the Second World. War there has been a big expansion in infra-red spectrophotometry. The predominant use of the infra. red, so the introduction to the bibliography states, has been in structural analysis of inorganic materials, and it has been used only sparingly in inorganic structural and mineralogical studies. Spectral analysis of emitted radiation within the near infra-red, 1-5 $\mu$ wave-length, has recently become of interest because of the study of nose cone re-entry and the problems of heat dissipation from refractory coatings. The bibliography lists 440 reforences together with in most cases the volume and number of Chemical Abstracts. The subject index contains 1,200 items and the author index includes all authors listed in the Chemical Abstracts of the original article. Details of the five existing bibliographies of the infra-red covering a wider field than that applicable to minerals are included in the bibliography, in addition to a survey of the countries of origin of works cited in the bibliography.

\section{Carbon Molecular Spectrum}

InfORMATION concerning the $\mathrm{C}_{2}$ molecule is of importance in many astrophysical problems. Nine electronic states of $\mathrm{C}_{2}$ have been identified from spectroscopic observations. Two recent papers by E. A. Ballik and D. A. Ramsay (Astrophys. J., 137, 61, 86; 1963) extend and review our knowledge of the $\mathrm{C}_{2}$ spectrum. In the first paper the infra-red band system $A^{\prime}{ }^{3} \Sigma_{g^{-}}-X^{\prime}{ }^{3} \Pi_{u}$ is studied. The most interesting result is the detection of small perturbations of some rotational levols in the $A^{\prime}{ }^{8} \Sigma_{g}-$ state caused by the state $x^{1} \Sigma_{g}{ }^{+}$, and these confirm that the latter state is the ground state of the $\mathrm{C}_{2}$ molecule and not the $X^{\prime}{ }^{3} \Pi_{u}$ state. Tho second paper contains a new analysis of the Phillips system of $\mathrm{C}_{2}$, a general summary of the molecular constants for all known $\mathrm{C}_{2}$ states, and a set of revised Morse potential eurves for the various states which take into account the value at present accepted of the dissociation energy of $\mathrm{C}_{2}$.

\section{Forest Entomology in the Congo}

Volume 2 of Hôtes Entomologiques du Bois has now been issued by the Institut National pour l'Etude Agronomique du Congo two years after the first, which was concerned with Yangambi; this one embraces the Congo and Ruanda Urundi (Série Soientifique No. 100. Distribution au Congo au Rwanda et au Burundi. Observations Etologiques. By Prof. R. Mayne with the assistance of Prof. C. Donis. Pp. 514. Brussels: Institut National pour l'Etude Agronomique du Congo, 1962. 500 NF.). The main work is preceded by a list of 208 species of 